\title{
MEMBANGUN LOYALITAS PELANGGAN MELALUI PERBAIKAN PELAYANAN TEKNOLOGI INFORMASI MANAJEMEN AKUNTANSI RSUD MAJALAYA KABUPATEN BANDUNG
}

\author{
Oleh \\ Hendra Permadi $^{1)}$ \& Winna Sarikusumaningtyas ${ }^{2)}$ \\ 1,2Sekolah Tinggi Ilmu Ekonomi (STIE) Ganesha Jakarta \\ Email : ${ }^{1}$ hendrapermadi507@gmail.com \& ${ }^{2}$ w.forwinnot@gmail.com
}

\begin{abstract}
Abstrak
Keluhan pelanggan / pasien RSUD Majalaya umumnya diarahkan pada kualitas pelayanan yang dinilai masih rendah. Penyebabnya klasik, yaitu masalah keterbatasan dana, sehingga RSUD tidak bisa mengembangkan mutu layanannya secara baik khususnya dalam manajemen akuntansi karena pelayanan teknologi informasi masih terbatas dan kemampuan sumber daya manusia (SDM) juga rendah. Penelitian ini untuk mengetahui pelayanan Teknologi Informasi pada RSUD Majalaya yang telah menjadi BLUD, serta mengukur pengaruhnya terhadap loyalitas pelanggan. Serta memberikan gambaran bagi manajer dalam industri jasa rumah sakit tentang bagaimana sistem akuntansi berkembang, dipelihara, dan menyediakan informasi keuangan dari waktu ke waktu. Tujuannya adalah untuk menemukan prinsip, konsep, prosedur dan aturan yang luas bagi penggunaan manajemen dalam suatu sistem akuntansi yang sehat untuk membuat keputusan dan memperoleh efisiensi, efektivitas dan keuntungan bisnis. Penelitian ini menggunakan metode survey deskriptif dan eksplanatori dengan unit analisis adalah pelanggan / pasien dengan sampel 80 orang. Berdasarkan hasil perhitungan nilai koefisien jalur variabel (X) terhadap (Y), yang didapatkan dengan menggunakan program SPSS releasse 18 for windows. Dengan menunjukkan bahwa harga $t_{\text {hitung }}$ jatuh didaerah $\mathrm{H}_{0}$ ditolak artinya koefisien jalur signifikan, sehingga diagram jalur tidak mengalami perubahan. Hasil analisis didapatkan bahwa Pelayanan Teknologi Informasi yang dilakukan ditanggapi positif oleh pelanggan/pasien.
\end{abstract}

Kata Kunci : Pelayanan Teknologi Informasi \& Loyalitas Pelanggan

\section{PENDAHULUAN}

Dengan terbitnya Peraturan Pemerintah (PP) Nomor 23 tahun 2005 tentang Pengelolaan Keuangan Badan Layanan Umum (BLU), maka status rumah sakit kini berubah menjadi BLUD. Paradigma baru pengelolaan keuangan negara sesuai dengan paket peraturan perundangundangan di bidang keuangan negara meliputi Undang-undang No. 17 Tahun 2003 tentang Keuangan Negara, Undang-Undang Nomor 1 Tahun 2004 Tentang Perbendaharaan Negara, dan UU Pemeriksaan Pengelolaan dan Tanggungjawab Keuangan Negara, setidaknya mengandung tiga kaidah manajemen keuangan Negara, yaitu: orientasi pada hasil, profesionalitas serta akuntabilitas dan transparansi.
Untuk sebuah rumah sakit yang menuju Rumah Sakit BLUD banyak hal yang turut menjadi komponen pendukung, maupun komponen bukan pendukung terhadap kegiatan rumah sakit tersebut. Tentu hubungannya dengan pembiayaan, penyusunan tarif maupun hal-hal yang lain yang berkaitan dengan keuangan.

Berdasarkan sifatnya manajemen rumah sakit adalah sebuah unit kerja yang dekat sekali dengan manajemen perhotelan. Di rumah sakit masalah yang besar adalah adanya pelayanan medik atau pelayanan kedokteran yang sifatnya terintegrasi. Jadi rumah sakit selain diperlukan profesionalisme manajemen perhotelan, masih diperlukan lagi profesionalisme dibidang kedokteran dan perawatan medik. 
Dua dekade terakhir ini adalah era pergerakan dan perubahan yang sangat besar dalam lingkungan bisnis. Revolusi ini memiliki efek yang sangat besar terhadap praktik akuntansi manajerial. Sejak tahun 1980-an, beberapa perusahaan telah melakukan serangkaian tahapan program perbaikan, dimulai dengan just-in-time (JIT), dan melalui manajemen mutu total (total quality management - TQM), Rekayasa Ulang Proses (process reengineering), dan serangkaian program manajemen, termasuk teori kendala (theory of constrains - TOC). Bila programprogram ini dijalankan dengan tepat, program perbaikan ini akan dapat meningkatkan kualitas, mengurangi biaya, meningkatkan output, mengurangi penundaan pelayanan, dan pada akhirnya meningkatkan laba.

Sesuai dengan Corporate Dominance Strategy Branding dalam rangka membentuk Brand Equity, maka diterapkan implementasi yang konsisten untuk terus meningkatkan kualitas pelayanannya untuk mencapai pelayanan yang unggul (service excellence), yaitu kecepatan, ketepatan, kenyamanan, dan keramahan, sehingga diharapkan masyarakat/pelanggan tetap memilih dan menggunakan produk-produk RSUD Majalaya yang pada gilirannya dapat meningkatkan market share di masa yang akan datang.

Bagaimanakah organisasi rumah sakit melakukan transformasi untuk menjadi lebih kompetitif, Dalam upaya menyelesaikan masalah manajemen akuntansi rumah sakit, haruslah kita ketahui dahulu dengan pasti apa saja yang dapat menjadi masalah dalam manajemen keuangan dan penyajian informasi, yang diperlukan sebagai pertanggung jawaban manajer dalam mengelola rumah sakit

Rendahnya loyalitas pelanggan RSUD Majalaya juga diperkuat dari hasil survey pendahuluan pada 10 orang pelanggan RSUD Majalaya. Diduga disebabkan oleh pelayanan Teknologi Informasi yang rendah relatif mempersulit pelanggan. Karena itu berdasarkan fenomena di atas, sangat penting untuk diadakan suatu penelitian, mengenai pengaruh pelayanan Teknologi Informasi terhadap loyalitas pelanggan.

Dengan pemikiran baru tersebut, diharapkan bukan bentuknya saja suatu unit pemerintah menjadi Badan Layanan Umum
Daerah (BLUD) yang melayani masyarakat tetapi tingkat pelayanan ditingkatkan dengan cara yang profesional, efektif dan efisien oleh pengelola unit tersebut dengan otonomi pengelolaan yang akan diberikan.

Rumah sakit BLUD adalah suatu institusi yang dalam pengelolaannya, melakukan kegiatan-kegiatan menyediakan barang, jasa, penentuan penyakit (diagnosa), kegiatan penyembuhan (terapi) dan kegiatan lain yang ada hubungannya dengan pengembalian fungsi seseorang menjadi sehat. Rumah sakit merupakan jenis usaha yang bergerak dibidang jasa pelayanan kesehatan. Rumah sakit juga suatu organisasi yang unik dan kompleks dikarenakan rumah sakit merupakan institusi yang padat karya, memiliki sifat-sifat dan ciriciri serta fungsi-fungsi yang khusus dalam proses menghasilkan jasa medik dan mempunyai berbagai kelompok profesi dalam menjalankan pelayanannya. Di samping melaksanakan fungsi pelayanan kesehatan masyarakat, rumah sakit memiliki fungsi pelatihan, pendidikan dan penelitian.

Pada lingkungan rumah sakit seperti ini, realitas keuangan memainkan peran penting dalam pengambilan keputusan bisnis, penting bagi manajer pada semua tingkatan memahami konsep dasar dari keuangan rumah sakit dan bagaimana konsep ini digunakan untuk menambahkan keuangan yang baik terhadap organisasi. Secara konsep diterangkan bahwa seluruh aspek Pelayanan Teknologi Informasi berpengaruh positif terhadap Loyalitas Pelanggan RSUD Majalaya.

\section{LANDASAN TEORI Manajemen}

Manajemen secara sederhana adalah kegiatan yang bewujud memonitor dan mengontrol, maka manajemen IT adalah usaha untuk memonitor dan mengontrol IT. Tugas memonitor harus dapat dilaksanakan dengan sebaik-baiknya, berarti segala kejadian dan aktivitasnya diketahui. Baru kemudian proses pengendalian atau kontrol sesuai dengan keinginan kita dapat dilaksanakan. Suatu bisnis 
akan efektif bila pada proses kendali utamanya ada suatu fungsi yang jelas dalam sistem manajemen, dan dilaksanakan dengan baik bersama sama pemonitoringannya.

Untuk itu, IT harus dilihat dari sudut mana dalam struktur manajemen. Karena IT dapat memegang fungsi tertentu dalam sistem manajemen perusahaan, maka perlu kepastian, agar dapat memperjelas dan memengerti fungsi sistem manajemen pada perusahaan, kemudian menempatkan IT pada manajemen yang dituju. Maka kita perlu mengerti terlebih dulu tentang sistem perusahaan.

\section{Akuntansi Dalam Rumah Sakit}

Akuntansi adalah keseluruhan pengetahuan dan fungsi yang berhubungan dengan penciptaan, pengesahan, pencatatan, pengelompokan, pengolahan, penyimpulan, penganalisaan penafsiran dan penyajian informasi yang dapat dipercaya dan penting artinya, secara sistematis. mengenai transaksitransaksi yang sedikit-sedikitnya bersifat finansial, dan yang diperlukan untuk pimpinan dan operasi sesuatu badan dan untuk laporanlaporan yang harus diajukan mengenai hal tadi guna memenuhi pertanggung jawaban yang bersifat keuangan atau lainnya (Paul Grady:2000).

Akuntansi pada umumnya merupakan suatu sistem untuk menghasilkan informasi keuangan yang digunakan oleh para pemakainya dalam proses pengambilan keputusan bisnis. Tujuan informasi tersebut adalah memberikan sumber daya yang langka pada aktivitas bisnis dan ekonomi.

Akuntansi Manajemen (Managerial Accounting) berkaitan dengan penyediaan informasi untuk manajer yaitu orang-orang di dalam organisasi yang mengarahkan dan mengendalikan operasi organisasi.

Apa peran akuntansi dalam Rumah Sakit ? Secara sederhana dapat dikatakan bahwa akuntansi dalam rumah sakit menghasilkan informasi yang digunakan manajer untuk menjalankan operasi rumah sakit. Secara umum, akuntansi rumah sakit dapat didefinisikan sebagai sistem informasi yang menghasilkan laporan kepada pihak-pihak yang berkepentingan mengenai aktiva ekonomi dan kondisi rumah sakit. Operasi bisnis rumah sakit, sama sifatnya dengan operasi bisnis lainnya. Operasi ini merupakan jumlah identifikasi umum atas perbedaan siklus pendapatan jasa.

Dalam kegiatan jasa rumah sakit, umumnya seorang manajer melakukan 3 kegiatan utama :

(1) Perencanaan (planning).

Perencanaan adalah mengidentifikasikan berbagai alternatif yang tersedia, dan memilih alternatif yang terbaik untuk memenuhi tujuan organisasi. Tujuannya adalah memperoleh laba bagi pemilik perusahaan dengan menyediakan pelayanan superior kepada pelanggan, dengan harga yang kompetitif. Rencana manajemen biasanya dijabarkan secara formal dan dalam bentuk penganggaran (budgeting) yang menggambarkan proses perencanaan secara umum.

(2) Pengarahan (directing) dan pemberian motivasi (motivating)

Dalam perencanaan di masa mendatang manajer harus memantau kegiatan seharihari. Dibutuhkan kemampuan untuk memotivasi dan mengarahkan para karyawan, pada tugas manajemen yang berkaitan dengan kegiatan rutin saat ini. Data akuntansi manajerial, seperti laporan penjualan harian, selalu digunakan untuk membuat keputusan harian.

(3) Pengendalian atau kontrol (controlling). Untuk melaksanakan fungsi pengendalian, Dalam pengendalian ini, manajer membutuhkan umpan balik (feedback), yang merupakan sinyal apakah operasi organisasi berada dalam jalur yang telah direncanakan. 
Gambar 1. Siklus Perencanaan Dan Pengendalian

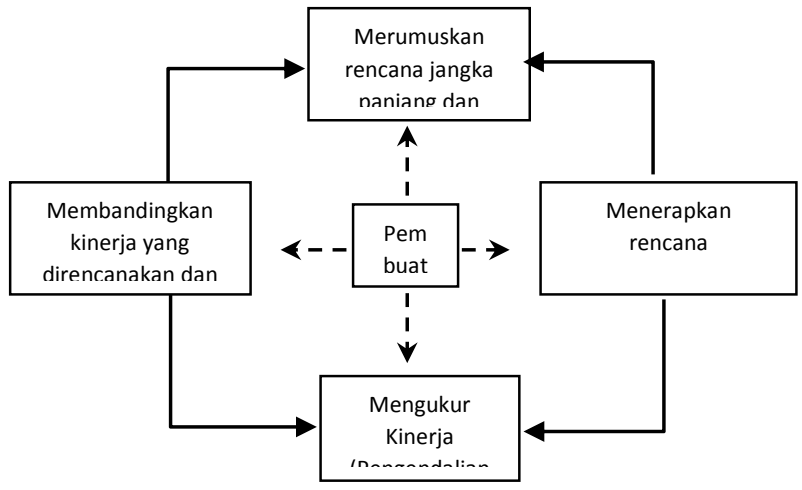

Dalam akuntansi rumah sakit, sekurang kurangnya ada 4 macam dana yang perlu diperhatikan dalam program pelayanan Teknologi Informasi, yaitu :

1. Dana Operasional (general fund)

2. Dana Pembangunan ( Plant Fund)

3. Dana untuk keperluan khusus (Specific Purpose Fund)

4. Dana Bantuan (Endowment Fund)

Dalam akuntansi sekurang-kurangnya ada lima hal lain yang perlu pula mendapat perhatian khusus kita, yaitu :

a) Uang Pemasukan (Revenue)

Semua uang pemasukan akibat biaya yang dibebankan atas pelayanan yang kita berikan kepada pasien, termasuk ke dalam kategori uang pemasukan atau revenue.

b) Uang pengeluaran (expense)

Gaji pegawai, bahan-bahan, biaya-biaya lain. Semua pembiayaan dalam pelaksanaan termasuk pengeluaran.

c) Aset.

Semua barang yang dipunyai dan dipergunakan oleh rumah sakit yang ada nilai uangnya, dikatakan aset. Investasi jangka panjang, maupun uang pendapatan harian dikatakan adalah aset rumah sakit. Gedung, peralatan dan uang pendapatan harian dimasukan kedalam kategori aset rumah sakit.

d) Jaminan

Hipotik, utang yang belum lunas, maupun barang, alat yang sedang digunakan tetapi belum dilunasi, dikatakan jaminan. Karena pada waktu sedang dipakai tetapi belum sepenuhnya milik rumah sakit, karena masih belum lunas.

e) Modal.

Semua aset yang tidak terutang disebutkan modal Rumah Sakit.

Untuk mengetahui lebih jelas apa dan dimana saja adanya pembiayaan, kita harus mengenal dahulu apa yang disebut dengan pusat-pusat biaya (cost centers). Ada 3 macam hal yang menjadi pusat-pusat biaya, yaitu :

1). Pusat Biaya Yang Tidak Menghasilkan Pendapatan (nonrevenue - Producing Cost centers),

2) Pusat Biaya Yang Menghasilkan Pendapatan (Revenue - Producing Cost Centers),

3). Area Pelayanan Pasien (Patient Sevice Areas)

Seluruh aktifitas kerja adalah proses, proses tersebut melibatkan prosedur-prosedur, tugas-tugas, jadwal-jadwal, mekanismemekanisme, aktifitas-aktifitas dan rutinitasrutinitas dengan apa produk (barang atau jasa) disalurkan ke pelanggan. Identifikasi manajemen proses sebagai aktifitas terpisah adalah prasyarat bagi perbaikan jasa. Pentingnya elemen proses ini khususnya dalam bisnis jasa disebabkan oleh persediaan yang tidak dapat disimpan, sebagaimana yang disampaikan oleh Haksever, Render, Russel, and Murdick (2000) menyatakan bahwa elemen dari proses adalah activities, tasks, routins, mechanisms, schedules, dan procedures.

Di bawah ini akan diuraikan mengenai pelayanan Teknologi Informasi RSUD Majalaya yang mencakup prosedur-prosedur, tugas-tugas, jadwal-jadwal, mekanismemekanisme, aktifitas-aktifitas dan rutinitasrutinitas dan kegiatan lainnya yang berhubungan manajemen akuntansi. 
Tabel 1. Cakupan Pelayanan Teknologi Informasi

\begin{tabular}{|l|l|}
\hline Indikator Skor & \\
\hline $\begin{array}{l}\text { Aktivitas dalam Menangani } \\
\text { keluhan pelanggan/pasien }\end{array}$ & 304 \\
\hline $\begin{array}{l}\text { Kecepatan dalam menangani } \\
\text { keluhan pelanggan/pasien }\end{array}$ & 304 \\
\hline $\begin{array}{l}\text { Respon dalam menangani keluhan } \\
\text { pelanggan/pasien }\end{array}$ & 290 \\
\hline $\begin{array}{l}\text { Rutinitas dalam melayani } \\
\text { pembayaran dan penagihan }\end{array}$ & 304 \\
\hline $\begin{array}{l}\text { Kemudahan jakan } \\
\text { pembayaran }\end{array}$ & 292 \\
\hline $\begin{array}{l}\text { Kejelasan tanggal jatuh tempo } \\
\text { pembayaran }\end{array}$ & 290 \\
\hline Kejelasan informasi Layanan & 294 \\
\hline Kejelasan jadwal pelayanan & 289 \\
\hline $\begin{array}{l}\text { Kejelasan Aturan-aturan } \\
\text { penggunaan fasilitas }\end{array}$ & 298 \\
\hline $\begin{array}{l}\text { Kemudahan melakukan } \\
\text { pendaftaran menjadi pasien }\end{array}$ & 287 \\
\hline Rata-rata Skor & $\mathbf{2 9 5 , 2}$ \\
\hline
\end{tabular}

Sumber : Hasil Pengolahan Data , Jan 2020

Berdasarkan tabel di atas, terlihat bahwa aktivitas dalam melayani pelanggan, kecepatan dalam melayani keluhan pelanggan, dan rutinitas dalam melayani pembayaran dan tagihan memiliki skor tertinggi. Sedangkan kemudahan melakukan pendaftaran menjadi pelanggan memiliki skor terendah. Hal ini menunjukkan bahwa proses awal yang dimiliki RSUD Majalaya relatif dinilai kurang oleh pelanggan, sedangkan ketika pelanggan sudah menggunakannya, RSUD Majalaya memberikan pelayanan Teknologi Informasi yang dinilai baik.

Padahal menurut Haksever, Render, Russel, and Murdick (2000) menyatakan bahwa elemen dari pelayanan Teknologi Informasi harus semuanya diperhatikan, terutama pada proses awal dari activities, tasks, routins, mechanisms, schedules, dan procedures.

\section{Pelayanan teknologi informasi}

Pengertian awalnya adalah dari "IT Service", merupakan suatu ungkapan yang mengandung arti khusus. Bila diterjemahkan menjadi bahasa Indonesia "Layanan Teknologi Informasi”, dengan maksud menunjukkan kumpulan pengetahuan yang detail maupun integral terhadap IT (Information Technology) yang digunakan untuk membantu layanan yang diberikan perusahaan. Dari setiap aktivitas yang dilakukan adalah bentuk layanan yang ditimbulkan IT, hasilnya bisa berbagai hal termasuk dalam lingkup untuk manajemen Perusahaan.

Obyek Teknologi Informasi ini secara pengetahuan harus diatur sedemikian rupa agar mudah dimengerti, ada urutan, ada kaitan satu dengan lainnya, dapat membantu layanan perusahaan, saling menjelaskan dan saling menguatkan, sehingga terbangun ilmu pengelolaan IT. Pengelolaan baik terhadap sumberdaya IT maupun sumber daya manusia yang di rangkai dalam framework dan aktifitas tertentu, dalam rangka memudahkan, mengefektifkan pengelolaan perusahaan.

Layanan Teknologi Informasi sebagai bagian pengelolaan atau manajemen perusahaan, adalah penyatuan berbagai bidang keilmuan dalam rangka penggunaan dan pemanfaatan IT.

Layanan (service) adalah sarana penyampaian nilai (Value Delivery) kepada pelanggan dengan memfasilitasi hasil akhir yang diinginkan pelanggan tanpa kepemilikan atas biaya dan resiko tertentu. Information Technology Service merupakan layanan TI yang disediakan oleh penyedia layanan untuk pelanggan (IT Service Customer) baik internal maupun eksternal, yang bertujuan untuk membantu berjalannya proses bisnis yang ada. Dalam layanan TI harus memperhatikan tiga domain berikut;

1. People, Domain berkaitan dengan organisasi perusahaan, job description, fungsi-fungsi yang ada di perusahaan

2. Process, Terkait dengan proses bisnis, tata kelola. Prosedur yang ada di perusahaan

3. Technology, Merupakan suatu tools yang digunakan untuk menjalankan setiap bisnis proses bisnis, sehingga mampu meningkatkan efektifitas dan efisiensi dari proses bisnis organisasi. 
Information Technology Service Management (ITSM) adalah suatu cara untuk menyelaraskan antara penyedia layanan TI dengan kebutuhan bisnis organisasi, sehingga mampu memberikan layanan TI lebih efektif serta efisien yang berorientasi kepada kebutuhan bisnis organisasi. Secara filosofis terpusat pada perspektif konsumen layanan TI terhadap bisnis suatu organisasi. ITSM dapat diimplentasikan dalam berbagai jenis organisasi yang telah menggunakan Teknologi Informasi dalam proses bisnisnya. ITSM memberikan keuntungan kepada perusahaan dan membantu perusahaan dalam mencapai tujuan strategis, sehingga ITSM dapat membuat suatu organisasi memiliki daya saing yang baik.

ITSM, sebagai suatu solusi manajemen, jelas tidak hanya terkait dengan ketersediaan infrastruktur TI, melainkan bagaimana infrastruktur tersebut dapat digunakan untuk meningkatkan kualitas layanan TI di lingkungan organisasi, sehingga lebih efisien dan efektif, yang berujung pada kemampuan dalam mengoptimalkan layanan kepada pelanggan. Langkah nyatanya organisasi pun akan dapat dengan mudah membuat perencanaan (forecasting) kedepan, termasuk juga dalam mengambil berbagai keputusan bisnis yang lebih dinamis

Manfaat dari Manajemen Layanan Sistem Informasi diantaranya:

Organisasi yang akan menggunakan layanan sistem informasi adalah untuk mengelolah banyak transaksi yang kita butuhkan, mengurangi biaya atau menghemat biaya dan juga bisa menghasilkan banyak pendapat untuk mereka semua. Maka dari itu kita semua akan merasa lebih mudah dalam mengerjakan apapun dengan layanan sistem informasi.

\section{Peranan Manajemen Layanan Sistem Informasi:}

Layanan sistem informasi memiliki banyak peran yang sangat efektif dan juga sangat penting bagi organisasi manapun. Layanan sistem informasi memiliki banyak peran juga dalam kegiatan-kegiatan bisnis yang sangat operasional, dan juga menunjang organisasi agar dapat mengambil kesimpulan, dan juga banyak menunjang keungulan strategi kompetitif dalam organisasi.

Peranan manajemen layanan sistem informasi bagi lingkungan sekitar ialah sebagai berikut :

(1) Mendukung Operasional Bisnis.

Manajemen layanan sistem informasi menyediakan dukungan dalam operasional bisnis seperti akuntansi hingga penelusuran pesanan pelanggan maupun kegiatan-kegiatan bisnis yang dilakukan sehari-hari.

(2) Mendukung Keunggulan Strategis.

Sistem informasi yang dirancang sedemikian rupa dapat membantu mencapai sasaran mencapai sasaran yang dapat membantu bersaing dengan perusahan-perusahaan lainnya.

(3) Perencanaan Strategi Perusahaan dan Kebijakan

Untuk mengetahui selera konsumen serta peluang pasar.

(4) Meningkatkan Aksebilitas Data

Data dapat diakses secara cepat dan ontime dan akurat bagi pemakainya.

(5) Meningkatkan Strategi Suatu Layanan Secara Global dan Menyeluruh

Mampu meningkatkan persaingan bisnis secara global serta melakukan pengelolaan dan pengawasan pasar.

(6) Meningkatkan Efisiensi Kerja

Layanan sistem informasi berguna untuk mengolah berbagai macam transaksi, menekan biaya dan menghasilkan pendapatan sebagai salah satu produk atau pelayanan mereka.

(7) Meningkatkan Daya Saing Bisnis

Dengan semakin meningkatnya persaingan, manajemen layanan sistem informasi membantu sebuah perusahaan untuk bersaing di pasar bebas karena manfaatnya bagi perusahaan itu sendiri.

Beberapa hal yang harus diperhatikan antara lain adalah :

(1) Reporting 
Reporting dalam bentuk regular, yang telah tersusun dalam format tertentu serta timing yang sudah terjadwal - Reporting untuk keperluan khusus, dalam kapasitas manajemen tertentu, serta batasan yang telah jelas - Merupakan support pada executive.

(2) Request management

Bagaimana mengelola request agar sampai kepada penyedia service dalam suatu sistem, agar mendapatkan jasa layanan yang diinginkan

(3) Service level agreement management berhubungan dengan kualitas dari service yang dapat diberikan; - ukuran biasanya dalam prosentasi tentang uptime availability; average respons times; escalation procedures for problems.

(4) Knowledge management

Manajemen ini dalam rangka pengeloaan pengetahuan yang ada pada individu dalam perusahaan agar perusahaan dapat semakin berkembang, maju, semakin efektif.

(5) Asset management

Pengelolaan asset, baik asset riel, Fix asset, maupun asset maya; ini meliputi asset yang berarti apapun yang dianggap milik perusahaan.

(6) Notification

Pemberian tanda dalam rangka untuk memberikan suatu informasi yang penting

(7) Escalation

Sistem yang mengalami eskalasi berarti adanya sesuatu yang terjadi tampa diketahui, sedang kejadian telah belaku atau terjadi ber kali kali, sehingga bila itu suatu kesalahan, maka kesalaha ini telah bertumpuk-tumpuk.

(8) Help desk

Service kepada customer dalam rangka memberikan interface kepada customer melalui satu pintu, dan kemudian dapat diteruskan (kadang disebut juga service desk)

(9) Problem management

Merupakan bagian dalam applicable operational.

\section{METODE PENELITIAN}

Sifat penelitian ini adalah deskriptif dan verifikatif melalui pengumpulan data dilapangan, maka metode penelitian yang digunakan adalah metode descriptive survey dan metode explanatory survey melalui kuesioner dan bersifat causalitas. Unit analisis dalam penelitian ini adalah individu, karena hanya para pelanggan RSUD Majalaya yang dijadikan responden. Time horizon dalam penelitian ini adalah crossectional, karena informasi dari sebagian populasi (sampel responden) dikumpulkan langsung di tempat kejadian secara empirik, dengan tujuan untuk mengetahui pendapat dari sebagian populasi terhadap objek yang sedang diteliti.

Dalam penelitian ini ukuran sampel ditentukan oleh bentuk uji statistika yang akan digunakan. Uji statistika yang digunakan adalah analisis jalur (Path Analysis), dimana koefisien jalur pada dasarnya adalah koefisien korelasi. Dengan melakukan penelitian pendahuluan untuk memperoleh parameter $\mathrm{p}$ dimana penelitian dengan topik yang sama belum pernah dilakukan, maka diperoleh $\mathrm{p}$ (koefisien korelasi terkecil) $=0,317$; sehingga dengan $\mathrm{p}=0,278, \alpha=0,5 ;$ dan $\beta=0,05$; maka diperoleh ukuran sampel (n) minimal sebesar 79,9 dibulatkan menjadi 80 responden.

Sesuai dengan teknik penentuan sampel seperti yang telah dikemukakan di atas maka ukuran sampel dalam penelitian ini adalah minimum 80 pelanggan rumah sakit. Sedangkan pemilihan sampel dari populasi digunakan teknik sampel random sampling. Cara pengumpulan data dengan menggunakan kuesioner sebagai pengumpulan dari sumber data primer. Alat analisis yang digunakan pada penelitian ini adalah distribusi frekuensi untuk menganalisis metode survey deskriptif dan analisis jalur untuk menganalisis survey eksplanatori dengan pengujian hipotesis. 
HASIL DAN PEMBAHASAN

Pengaruh Pelayanan Teknologi Informasi

Terhadap Loyalitas Pelanggan RSUD

Majalaya

Untuk mengungkap pengaruh sebuah variabel atau seperangkat variabel terhadap varibel lain, dapat digunakan Analisis Jalur (Path Analysis) yang telah dikembangkan Sewall Wright. Pada analisis jalur ini besarnya pengaruh suatu variabel terhadap variabel lainnya, baik langsung maupun tidak langsung dapat diketahui. Sebelum mengambil keputusan mengenai besarnya pengaruh suatu variabel terhadap variabel lainnya tersebut, terlebih dahulu dilakukan pengujian hipotesis.

Untuk mengetahui apakah variabel bebas yaitu Pelayanan Teknologi Informasi (X) berpengaruh terhadap Loyalitas Pelanggan (Y) Pelanggan RSUD Majalaya dilakukan dengan menggunakan analisis jalur (path analysis) dan software yang digunakan adalah SPSS release 18.

Tabel 2. Pengujian Hipotesis X Terhadap Y

\begin{tabular}{|l|l|l|l|l|}
\hline $\begin{array}{l}\text { Koefisien } \\
\text { Jalur }\end{array}$ & & $\mathbf{t}_{\text {hitung }}$ & $\mathbf{t}_{\text {tabel }}$ & Kesimpulan \\
\hline Pyx & 0.650 & 6.025 & 1.645 & $\begin{array}{l}\text { Ho tolak } \\
\text { Terdapat pengaruh } \\
\text { positif Pelayanan } \\
\text { Teknologi } \\
\text { Informasi terhadap } \\
\text { Loyalitas } \\
\text { Pelanggan }\end{array}$ \\
\hline
\end{tabular}

Sumber : hasil perhitungan

Berdasar hasil perhitungan nilai koefisien jalur variabel $(\mathrm{X})$ terhadap $(\mathrm{Y})$, yang didapatkan dengan menggunakan program SPSS releasse 18 for windows, Dengan demikian sesuai dengan kaidah keputusan, bahwa harga thitung jatuh didaerah $\mathrm{H}_{0}$ ditolak artinya koefisien jalur signifikan, sehingga diagram jalur tidak mengalami perubahan. Secara konsep dapat dijelaskan bahwa seluruh aspek Pelayanan Teknologi Informasi berpengaruh positif terhadap Loyalitas Pelanggan RSUD Majalaya.
Gambar 2. Diagram Jalur Pengaruh Pelayanan Teknologi Informasi (X) terhadap Loyalitas Pelanggan (Y)

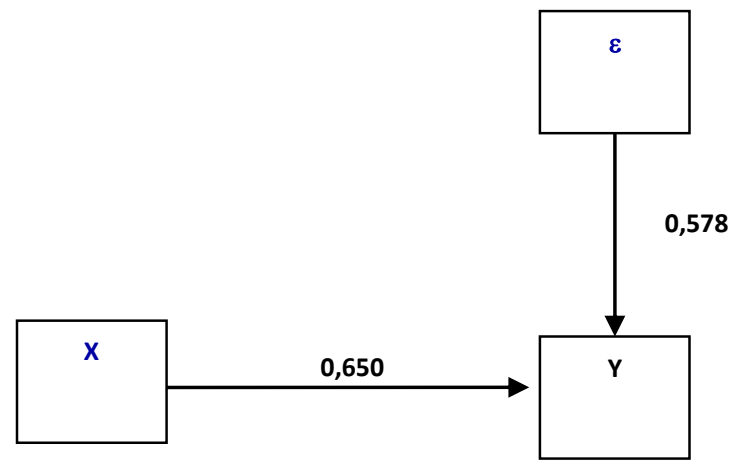

Dari gambar 2 diatas struktural hubungan kausal antar variabel dengan nilai-nilai parameter struktur di atas, maka pengaruh dari variabel penyebab ke variabel akibat, maka pengaruh Pelayanan Teknologi Informasi terhadap Loyalitas Pelanggan RSUD Majalaya adalah :

Tabel 3. Pengaruh Variabel $X$ ke $Y$ dan Pengaruh Diluar Sub Variabel

\begin{tabular}{|l|c|c|}
\hline \multicolumn{3}{|l|}{ Interpretasi Analisis Jalur } \\
\hline Keterangan & Pengaruh & \% \\
\hline Pengaruh X ke Y & 0.422 & 42.2 \\
\hline Pengaruh Diluar X & 0.578 & 57.8 \\
\hline Jumlah & & 100 \\
\hline
\end{tabular}

Sumber : Hasil Pengolahan Statistik Program SPSS, Jan 2020

Dari hasil pengujian dapat diketahui bahwa Pelayanan Teknologi Informasi berpengaruh terhadap Loyalitas Pelanggan yakni sebesar $42.2 \%$, sedangkan sisanya sebesar $57.8 \%$ dipengaruhi oleh faktor-faktor lain yang tidak diteliti oleh penulis.

Berdasarkan hasil pengujian di atas ternyata bahwa faktor Pelayanan Teknologi Informasi berpengaruh terhadap Loyalitas Pelanggan, hal ini didasarkan kepada tingkat kontribusi Pelayanan Teknologi Informasi terhadap Loyalitas Pelanggan yang mencapai hanya $42,2 \%$. Di sini dapat dilihat bahwa para Pelanggan lebih suka pada proses aktivitas dalam pelayanan, kecepatan mendapatkan tanggapan komplain yang dinilai baik.

Hasil Analisis di atas, sesuai dengan pendapat Belch \& Belch (2001; 64), 
menyatakan, iklan merupakan salah satu bentuk utama dari komunikasi impersonal yang digunakan oleh perusahaan jasa, dengan tujuan untuk membangun kesadaran akan pentingnya jasa, menambah pengetahuan pelanggan dalam membeli dan membedakan suatu jasa dengan jasa lain yang ditawarkan.

Kotler \& Keller (2006: 471), elemen process ini mempunyai arti suatu upaya perusahaan, dalam menjalankan dan melaksanakan aktifitasnya untuk memenuhi kebutuhan dan keinginan konsumennya. Untuk perusahaan jasa kerjasama antara pemasaran dan operasional sangat penting dalam elemen process ini, terutama dalam melayani segala kebutuhan dan keinginan konsumen. Karena jika dilihat dari sudut pandang konsumen, produk jasa dilihat dari bagaimana process jasa menghasilkan fungsi.

Lovelock and Wright (2002: 55), setelah elemen-elemen jasa diproses dan dibuat dalam sistem operasi jasa, maka elemen-elemen jasa tersebut dirakit/ dibentuk dalam sistem penyampaian jasa menjadi elemen jasa yang utuh dan siap ditawarkan pada konsumen. Sistem penyampaian jasa difokuskan pada dimana, kapan, dan bagaimana elemen-elemen jasa tersebut dalam hal ini elemen-elemen jasa yang direspon langsung oleh konsumen, yaitu elemen-elemen bauran pemasaran jasa disampaikan pada konsumen.

Menurut Oliver (1997:392) loyalitas pelanggan adalah komitmen untuk bertahan secara mendalam untuk melakukan pembelian ulang atau berlangganan kembali produk atau jasa terpilih secara konsisten di masa yang akan datang, karena pelayanan Teknologi Informasi dari perusahaan tersebut baik.

\section{PENUTUP}

Pada manajemen akuntansi Rumah Sakit BLUD perlu diperhatikan banyak hal. Selain situasi dan kondisi Rumah Sakit yang dikelola, perlu ditinjau berbagai hal sesuai dengan apa yang dimaksud dalam definisi manajemen akuntansi, yaitu :

- Keseluruhan pengetahuan dan fungsi yang berhubungan dengan penciptaan, pengesahan, pencatatan, pengelompokan, pengolahan, penyimpulan, penganalisaan, penafsiran dan penyajian informasi yang dapat dipercaya dan penting artinya, secara sistematik mengenai transaksi- transaksi yang sedikit-sedikitnya bersifat finansial, dan yang diperlukan untuk laporan laporan yang harus diajukan mengenai hal tadi guna memenuhi pertanggung jawaban yang bersifat keuangan dan lainnya.

- Perlu diperhatikan secara seksama apa yang telah diuraikan di atas, dengan kata lain semua kegiatan di Rumah Sakit adalah berimplikasi dengan keuangan, apakah itu merupakan cost (biaya) tapi dapat pula merupakan reveneu (pemasukan). Transaksi dapat pula berupa kredit, atau tunai, yang akibatnya untuk suatu bagian merupakan income berupa barang atau inventarisnya bertambah, sedang dibagian lain berupa hutang, walaupun belum ada pengeluaran uang yang terjadi. Dengan demikian, manajemen akuntansi rumah sakit menarik untuk dipelajari dan ditekuni lebih jauh dan lebih dalam apalagi Rumah Sakit tersebut telah menjadi Rumah Sakit Badan Layanan Umum Daerah (BLUD).

- Pelayanan Teknologi Informasi ditanggapi positif oleh pelanggan RSUD Majalaya, terutama aktivitas dalam melayani pelanggan, kecepatan dalam melayani keluhan pelanggan, dan rutinitas dalam melayani pembayaran dan tagihan memiliki skor tertinggi. Sedangkan kemudahan melakukan pendaftaran menjadi pelanggan dinilai kurang baik. Hal ini menunjukkan bahwa proses awal yang dimiliki RSUD Majalaya relatif dinilai kurang oleh pelanggan, sedangkan ketika pelanggan sudah menggunakannya, RSUD Majalaya memberikan pelayanan Teknologi Informasi yang dinilai baik.

- Pelayanan Teknologi Informasi berpengaruh terhadap loyalitas pelanggan RSUD Majalaya, Sehingga dengan pelayanan Teknologi Informasi yang baik akan membuat pelanggan loyal dan termotivasi bekerja di RSUD Majalaya. 
DAFTAR PUSTAKA

[1] Grady, Paul, 2000, Teori Akuntansi, Erlangga, Jakarta

[2] Belch, George E., Belch, Michal, A. (2001). Advertising and Promotion: An Integrated Marketing Communication Perspective, $8^{\text {th }}$ Edition. New York: Pearson Education.

[3] Chisnall, Peter M., 1995, Strategic Business Marketing, $3^{\text {rd }}$ Edition, University Press, Cambridge.

[4] Consuelo Sevilla, G, 1998, An Introduction to Research Methods, Rax Printing Company, New York.

[5] Haksever, Cengiz, Berry Render, Roberta S Russel, and Robert G Murdick 2000, Service Management and Operation, Second Edition,Prentice Hall International, USA.

[6] Haksever, Cengiz, Berry Render, Roberta S Russel, and Robert G Murdick 2000, Service Management and Operation, Second Edition, Prentice Hall International, USA.

[7] Al-Rasjid, Harun, 1998, Analisis Jalur Sebagai Sarana Statistik Dalam Analisis Kausal,LP3-UNPAD, Bandung.

[8] Kotler dan Keller, 2006, Marketing Management, , Prentice Hall International, Inc. A Division of Simon \& Scuster, Englewood Cliffs, Nj07632.

[9] Lovelock, Christoper,H and Lauren. K. Wright, 2002, Service Marketing and Management, Prentice Hall International, Inc. New Jersey.

[10] Oliver, Richard L. 1997. Satisfaction: A Behavioral Perspective on the Consumer, McGraw Hill: New York.

[11] Sekaran, Uma, 2000, Research Method for Business, International Edition, Prentice Hall, USA

[12] Walker, Orville C, Harper W Boyd, and Jean Claude Larreche, 1999, Merketing Strategy : Planning and Implementation, Third Edition, Irwin McGraw-Hill, Boston

[13]Arfan Ikhsan, Ida Bagus Agung Dharmanegara, 2010, Akuntasi dan
Manajemen Keuangan Rumah Sakit, Graha Ilmu, Jakarta

[14]Azrul azwar, Pengantar Administrasi Kesehatan. Jakarta :Bina rupa aksara, 1988

[15]F.J Bennett. Diagnosa Komunitas Dan Program Kesehatan. Jakarta : Yayasan essentica Medica, 1987

[16] Hadibroto; Lubis, dachnial dan sukadam, sudrajat. Dasar - dasar Akuntansi. Jakarta: LP3ES, 1991

[17]Metha. Natin dan Maher Donald J. Hospital Accounting Systems And Controls.Englewood Cliffs : Prentice Hall, 1977 